\title{
"One Belt One Road" Initiative and China and the Middle East Media Exchanges
}

\author{
QIAN Xuming \\ Shanghai International Studies University, Shanghai, China
}

\begin{abstract}
The proposal of the "One Belt One Road" initiative has brought historic opportunities for media exchanges between China and the Middle East, and has also put forward higher requirements for media cooperation between the two sides. At present, media exchanges between China and the Middle East have made positive progress, but there are still some problems. To do a good job in media exchange and cooperation between China and the Middle East, we should start with the implementation and improvement of existing mechanisms, the transformation of media working methods and concepts, the broadening of communication channels, the concern for interests, and the strengthening of personnel training, so as to continuously improve the effectiveness of media exchange and cooperation between the two sides and promote the healthy development of bilateral relations.
\end{abstract}

Keywords: media exchanges between China and the Middle East, the Arabia world, discourse power

\section{Introduction}

Chinese and foreign media are the disseminators, participants, and builders of the community of human destiny. As the General Secretary Xi Jinping said, "the construction of the 'One Belt One Road' Initiative should overcome estrangement between civilizations via exchanges, overcome civilization conflicts through mutual understanding, and transcend the superiority of civilizations via civilizations coexistence, and promote mutual understanding, mutual respect and mutual trust among nations".

The "One Belt One Road" Initiative is a road of peaceful cooperation, openness, tolerance, mutual learning, and mutual benefit. China advocates the construction of a community of human destiny, promotes the reform of the global governance system, and further improves China's international influence, inspiration, and shaping power. All these have greatly improved the international conditions for the development of China's media, and created a new historic opportunity for China to promote the capacity-building of international communication, to tell good Chinese stories, to present a true, three-dimensional, and comprehensive picture of China, and to enhance the cultural soft power of the country. In the construction of "One Belt One Road", the domestic media should carry out public diplomacy and non-governmental exchanges through organizing dialogues and news and cultural exchanges of rich content and various forms, and create more dialogue and communication platforms to bring closer relations among all countries and regions. The Chinese media must do a good job of "Heart-to-heart project" between Chinese and foreign people.

\footnotetext{
"Acknowledgement: The paper is sponsored by Shanghai Pujiang Program.

QIAN Xuming, Ph.D., Associate Professor, Middle East Institute, Shanghai International Studies University.
} 
The Middle East is one of the world's oil valves, which connects Asia, Africa, and Europe, strangles the transportation hub between the Eastern and Western hemispheres, and concentrates huge natural gas and oil reserves and important mineral resources, including gold. The Middle East is also the birthplace of Islasm, Christianity, and the Islam, and has important social and cultural significance. The proposal of the "One Belt One Road" Initiative has brought historic opportunities for media exchanges between China and the Middle East, and has also put forward higher requirements for media cooperation between the two sides.

\section{China's Achievements in Media Exchanges With the Middle East Countries}

The media exchanges between China and the Middle East can be traced back to 1950s. In 1955, at the invitation of the China Journalists Association, a delegation of six people from Egyptian news agencies visited China and was cordially received by then Premier Zhou Enlai. In December 1956, a delegation of Chinese journalists arrived in Cairo to implement the China-Egypt Cultural Cooperation Agreement of 1956 and to visit Egypt. They were met by Ahmed Hassan Bakuri, Minister of Religious Funds of Egypt, and Mustafa Yusuf, and then Deputy Minister of Foreign Affairs of Egypt. ${ }^{1}$ Since then, journalists and news delegations, as well as officials of the government's press departments and news leaders of political parties, from Algeria, Somalia, Sudan, Morocco, Tunisia, and other Arab countries and regions have successively visited China. During their visits to China, some of them were also met by Mao Zedong, Zhou Enlai, Deng Xiaoping, and other leaders of the old and new generation of Chinese leaders. In October 1981, a delegation of Chinese journalists arrived in Mogadishu, the capital of Somalia, and began a four-day visit to Somalia. The delegation was received by President Siad. In March 1992, at the invitation of Egyptian press Al-Ahram, a delegation of China's People's Daily headed by then Chief Editor Shao Huaze arrived in Cairo for a friendly visit to Egypt. Egyptian Information Minister Sharif met with Shao Huaze and his delegation in Cairo (Wang, 2011).

Since the beginning of the new century, the friendly and cooperative relations between China and the Middle East countries have made new progress. In September 2004, China and Arab countries signed the Declaration of the China-Arab State Cooperation Forum. On the same day, China and Arab countries also signed the Action Plan of the China-Arab State Cooperation Forum. Since then, media exchanges and cooperation between China and Arab countries have begun to be carried out with many forms, channels, and levels. The scale and frequency of the exchange are greater and richer than before.

\section{Communication Covers a Wider Range and Contacts Become More Frequently}

The media exchange between China and the Middle East covers all aspects related to it, including the exchanges between government news departments, as well as between radio, television stations, and print media of both sides. The scale and frequency of the exchanges have entered a new stage.

Almost all the central media and news organizations in China have various exchanges and cooperation with the media of the Middle East countries, including People's Daily, Xinhua News Agency, CCTV, China Radio International, and the China Association of Journalists, which receive visiting media delegations or heads of media from the Middle East countries every year and visit the Middle East for interviews and reports annually. Some Chinese media have also established regular exchanges and cooperation mechanisms with the Middle East media (Wang, 2011). In terms of radio and television media exchanges, the Arabic-language channel of China Radio International, which started in 1957, broadcasts 22 hours a day and is widely welcomed

${ }_{1}$ The Deputy Minister of Foreign Affairs of Egypt received the Chinese delegation of journalists. People's Daily, 1956-12-11 
by listeners in the Middle East countries. In July 2009, China Central Television launched a 24-hour Arabic channel to transmit television signals through Arabsat and Nilesat satellites, covering the Middle East and North Africa, as well as the Asia-Pacific region through Zhongxing 6B satellite. People in the Middle East can watch programs from China through home satellite receiving antennas. ${ }^{2}$ In 2011, the first China-Arab Radio and Television Cooperation Forum was held, and was held every two years thereafter. Through this forum, the bilateral and multilateral exchange and cooperation mechanism for radio and television media of China and Arab has become more mature (Zhang, 2015). In terms of the exchange of publications, in October 2004, the Arabic edition of China Today established the Middle East Branch in Egypt. The readership of the magazine includes not only the upper level in the Arab, businessmen and intellectuals concerned about China, but also the lower-level social groups. In the field of print media exchange, Wuzhou Communication Publishing House, Ningxia People's Publishing House, Foreign Language Publishing House, Foreign Language Teaching and Research Publishing House, Higher Education Publishing House, and Beijing Language and Culture University Publishing House are pioneers. For example, Wuzhou Communication Publishing House has published a series of books in Arabic, covering all aspects of Chinese society, which includes history and geography, legal and customs, politics and diplomacy, Wushu and Chinese medicine, Art and Tourism, and so on. In 2013, the China-Arab Publishing Cooperation Forum and Copyright Trade Fair, with the theme of "Inheriting Friendship, Deepening Cooperation and Common Development", was held in Ningxia and became an important part of the Sino-Arab Expo (Chen, 2014). In April 2017, the China-Arab Publishing Development Summit was held at the 27 Abu Dhabi International Book Fair. The representatives of Chinese media launched a dialogue with the representatives of Arabia publishing circles on the theme of China-Arab Publishing Cooperation under the "One Belt One Road" Initiative. ${ }^{3}$

\section{The Content of Communication is More Abundant}

(1) The number of branch offices and press stations is increasing. China's Xinhua News Agency has branches in 14 Middle East countries and regions, including Egypt, Tunisia, Yemen, Saudi Arabia, Morocco, Kuwait, Sudan, Palestine, Syria, Lebanon, Iraq, Jordan, Algeria, and the United Arab Emirates. The People's Daily has branches in Egypt, Syria, Tunisia, and Sudan. China Radio International has a press station in Egypt and Qatar respectively. Following the establishment of Egyptian Middle East News Agency's Beijing branch, Qatar Peninsula Television in 2002 and Morocco News Agency (Maghreb Arab News Agency) in 2005 also set up branches in Beijing.

(2) The sharing of news resources and personnel cooperation has been further strengthened. In July 2001, the Xinhua News Agency signed a news exchange and cooperation agreement with Egypt's Middle East agency in Cairo. In June 2007, the All-China Journalists Association and the Tunisian Journalists Association signed an agreement of friendship and cooperation in Tunisia. The two sides agreed to work together to promote cooperation between journalists of the two countries and strengthen mutual ties.

(3) There are various forms of communication such as seminars and training courses. In August 2004, the Information Office of the State Council of China held the first news seminar for government officials of African countries in China. Since then, almost every year, there have been news officials and journalists

\footnotetext{
2 Yongli, “CCTV Arabian international channel's international impact is rising”. CCTV Network, http://cctvenchiridion.cctv.com/20110725/107001.shtml, 25 July 2011.

3 Sun, Haiyue, "The China-Arab Publishing Development Summit Forum focuses on exchange and cooperation". China Press Publication Radio Film and Television Journal, 2017-4-28.
} 
from Arab countries attending the seminar. ${ }^{4}$ In May 2007, the Ministry of Commerce and the Communication University of China held a two-week radio and television news gathering and editing seminar for media personnel, including Arab media. ${ }^{5}$

\section{The Internet and New Media Exchanges Are Flourishing}

In May 2002, the Arabic website (arabic.cri.cn) of China Radio International was officially launched. This website not only enables the audience to browse and listen to the whole content of Arabic radio broadcasting of China Radio International, but also has network radio stations for netizens to enjoy music and network forums for netizens to interact. ${ }^{6}$

China's mainstream official media have launched their own Arabic online editions, such as the Arabic version of China Radio International, the Arabic version of China Central Television Network, People's Daily.com, and Xinhua.com. The Arabic online edition of these media has also opened an interactive space for Arabic readers, and has achieved initial results. For example, Xinhua's Arabic-language channel has opened official accounts on social media twitter (http://twitter.com/chinaarabic). Arabic-language version of China.com and Arabic-language version of China Radio.com have also opened official accounts on social media, such as twitter and Facebook. Xinhua News Agency has also tailored a mobile new media product with completely independent intellectual property rights for users in the United Arab Emirates-the mobile phone app of Xinhua in the United Arab Emirates, which is the only Chinese-Arab bilingual news information and service information app (Chen, 2014).

\section{Continuous Improvement of Media Communication Mechanism}

In September 2004, China and Arab countries signed the Declaration of the China-Arab State Cooperation Forum. On the same day, China and Arab countries also signed the Plan of Action of the China-Arab State Cooperation Forum. The plan of action carries out news cooperation through bilateral and multilateral channels and encourages major news media of both sides to strengthen exchanges. Both sides will continue to send news delegations to each other for interviews, so as to provide assistance and convenience for journalists stationed in the other side to carry out their work, and encourage the purchase of news and art materials from other sources through commercial channels. ${ }^{7}$ China and the Arab regularly hold the China-Arab News Cooperation Forum, which is held in major cities of China and the Arab in turns. So far, three press forums have been held, Moreover, the Memorandum of Understanding on Friendly Press Cooperation and Exchange between China and the member states of the League of Arab States has been signed, and three press bulletins of the Cooperation Forum have been issued.

In 2011, the first China Arab Radio and Television Cooperation Forum was held in Ningxia, and it was held every two years. Through this forum, the bilateral and multilateral exchange and cooperation mechanism of China-Arab radio and television media will be more mature and complete.

In addition, several of the Middle East countries are African countries, and most of them are members of the China-Africa Cooperation Forum. Therefore, these countries belong to both the Middle East and Africa, and

\footnotetext{
4 "Members of the Sixth African Government Officials Journalism Seminar visited Chongqing" [EB/OL] [2009-07-20]. http://www.scio.gov.cn/ztk/dtzt/02/200907/t368145.htm.

5 "Completion ceremony of "African French speaking radio and television news gathering and editing seminar" [EB/OL]. [2007-06-13]. http://news.cuc.edu.cn/shownews.jsp?Newsid=1958.

${ }_{6}^{6}$ Excellent CRI-Arabic [EB/OL] [2010-09-20]. http://www.bclsky.com/bbs/Archiver.asp?Thread ID=1925.

7 "Action plan of the China-Arab State Cooperation Forum", Cairo, 14 September 2004, China-Arab State Cooperation Forum website, http://www.cascf.org/chn/wjk/bzjhywj/dijbzjhy/t866307.htm.
} 
the media exchanges and cooperation can be carried out within the framework of the China-Arab State Cooperation Forum and the China-African Cooperation Forum.

\section{Problems Existing in Media Exchanges Between China and the Middle East Countries}

Although the coverage rate of Chinese media in the world is almost the same as that of Western countries, there is a big gap between Chinese media and Western media in terms of international audience contact rate, residence rate, audience rate, and listening rate. The work of the media has not substantially improved China's international credibility and international public opinion leadership (Wu, 2011). This led to China's lack of discourse power in the Arabia world, which is not commensurate with its national strength. The internal reason is the lack of institutional mechanism, sense of diplomacy, participants, and means, while the external reason is related to the "discourse hegemony" of Western media in the international environment.

\section{Institutional and Mechanic Aspects}

In 2008, the first China-Arab News Cooperation Forum was held in Beijing. The two sides signed the Memorandum of Understanding on Friendly News Cooperation and Exchange between China and the member states of the League of Arab States, which marked the formation of a formal platform and mechanism for media exchanges between China and Arab countries. After 10 years of development, great progress has been made in media exchanges between China and Arab countries, but there are still some problems, such as the time lagging, lack of coordination, and lack of attention. Specifically, in terms of frequency, level, and scale of exchanges, media exchanges between China and Arab countries lag behind exchanges and cooperation in other fields; there is a lack of coordination in news work, especially in major international news and important events involving bilateral relations; and lack of cooperative reporting and coordinated response (Wang, 2011); News communication has not yet received enough attention.

\section{Sense of Diplomacy}

Mainstream Chinese media in Middle East countries lack a sense of the overall situation, and thus cannot effectively cope with the national strategy and its need to produce adequate and convincing news reports, nor can they argue and disprove when the country encounters major crises (Zhan, 2011). Since 2011, the outbreak of the Arab Spring in the Arab region has attracted great attention of the international community. On the Syrian issue, China voted three times against the resolution on Syria in the United Nations Security Council, which aroused the misunderstanding of some Arabs and the discontent of Gulf Cooperation Council (GCC) countries. Although China Daily's coverage of Syria presents China's diplomatic image of peace, justice, stability, and principled and historical perspective, Chinese media did not directly explain the choice of the Chinese government to the Arab people and resolve the misunderstanding of the Arab side about China.

\section{Subject and Means}

In addition to the official media, the unofficial media should also play a unique role in media exchanges and public diplomacy. However, there are not many non-governmental media engaged in relevant work, and without policy encouragement and guidance, the self-media is too scattered to present to the Arab world a more colorful China which is different from official promotion. It is also difficult for China to effectively promote private exchanges between the two sides. In terms of means of communication, the corresponding measures of 
Chinese media are limited to opening accounts in international social media, but these measures are only forms, and further efforts are needed to expand the influence of content and innovate working methods. Nowadays, the world has entered the era of media integration. Chinese traditional official media also pay attention to the use of Internet tools, update their Internet thinking, establish a matrix of international media including diversified media forms, and grasp the historical opportunity of the overall change of international media pattern.

\section{Public Opinion Environment}

The United States, Russia, Britain, France, and other Western countries have their own interests and strategic planning in the Middle East region for a long time. In addition, the developed countries are in the traditional dominant position in international politics. Their media have developed maturely in the Middle East region and become powerful to the local media. As a result of their influence, quite a part of Arab reports on China are directly or indirectly reproduced from Western media. In this case, the Western media's constant blasphemy of China can easily lead to misunderstanding and wrong perception of China in the Arab world, especially among ordinary people. The reports written by Arab journalists or scholars themselves are not comparable to those of the Western media in terms of quantity and influence. For this kind of "news agency reports" written through the secondary processing from Western media, it is not only difficult to achieve objective and impartial content, but also will inevitably have a negative impact on the Arab people's understanding of China (Lv, 2013).

In addition, in terms of talent reserve, China still lacks professionals who are familiar with Middle East language, culture, national conditions, and international relations. Talents training is also an important basis for promoting the long-term development of media exchanges between China and the Arab.

\section{Conclusion}

Under the context of "One Belt One Road" Initiative, we should improve the existing communication activities on the Silk Road. First, to step up the pace of "going out" of Chinese media, form an orderly, efficient, and unite external communication mechanism, and expand the popularity and influence of mainstream Chinese media in the Middle East countries (Chen, 2014). Secondly, to change the way and concept of media work, Chinese journalists should actively "go out" to the front line of work in the Arab world, so as to realize the direct exchange and cooperation between Chinese media and Arab media. They should tell Chinese stories well and innovating international communication arts and techniques in a way that is acceptable to Arab audiences. Thirdly is to grasp the cultural context and use polysemous discourse to disseminate appropriate content. In addition, the media exchanges between China and the Middle East should also include religious considerations and humanistic care, so as to express opinions in a way closer to the people's hearts.

\section{References}

Chen, J. (2014). China's media exchange with Arab countries since the establishment of the China-Arab State Cooperation Forum. $\quad$ Retrieved from http://mideast.shisu.edu.cn/_upload/article/33/e3/65a131074b75a69568c53a250ba0/9b153b4c-e11b-40bc-a216-eleabef7f71c.pdf

Lv, K. D. (2013). The image of China in Pan-Arab Newspapers (Master dissertation, Beijing Foreign Studies University).

Wang N. (2011). Sino-Arab media exchanges and cooperation. Arab World Studies, 1, 33-41.

Wu, L. B. (2011). Research on the international communication and impact of Chinese media (Dissertation, the Party School of the Central Committee of the Communist Party of China).

Zhan, L. Y. (2011). The image of China from the perspective of Arab media (Master degree thesis, Shanghai Foreign Studies University). 
Zhang K. (2015). Communication comes first to achieve the Interconnection of People's Hearts: National Communication Strategy for Serving the Construction of the Silk Road Economic Belt. People's Forum, Academic Frontier, (5), Part I.

Zhang, L. (2015). Radio and TV cooperation between China and Arab countries is getting better. Retrieved from http://news.xinhuanet.com/world/2015-09/09/c_1116510730.htm 